Timár, Eszter. 'Csehy, Zoltán. 2014. Szodoma és környéke: Homoszocialitás, barátságretorika és queer irányulások a magyar költészetben ('Sodom and its Environs: Homosociality, Friendship Rhetoric and Queer Orientations in Hungarian Poetry'). Budapest: Kalligram.." Hungarian Cultural Studies. e-Journal of the American Hungarian Educators Association, Volume 10 (2017) DOI: 10.5195/ahea.2017.308

\title{
Csehy, Zoltán. 2014. Szodoma és környéke: Homoszocialitás, barátságretorika és queer irányulások a magyar költészetben ('Sodom and its Environs: Homosociality, Friendship Rhetoric and Queer Orientations in Hungarian Poetry'). Budapest: Kalligram.
}

\author{
Reviewed by Eszter Timár , Department of Gender Studies, Central European University
}

Zoltán Csehy's eight-hundred page study, Szodoma és környéke, maps the history of Hungarian poetry, from its first record to contemporary works, looking at it through the lens of gender and, more specifically, homosexuality. It is a monumental tome that reads like a fascinating fold-out book spanning eight-hundred years of gendered patterns. Csehy presents and interprets primary texts in Hungarian and Latin, as well as influential Hungarian translations of foreign authors, ranging from Michelangelo to Allen Ginsberg, including selections from noncanonical sources such as the gay magazine Mások ['Others'] or Internet forums. All these texts are discussed with regard to the ways in which they present gendered tropes and how they influence or are influenced by other such texts of Western culture.

Csehy's accomplishments are multiple: he has created a history of queerness in Hungarian poetry, he traces the persistence of queerness tropes in this poetry throughout the longue durée, and he shows that this history is far more complex than revealing or hiding voices confessing their forbidden desire. Csehy's work pays attention to the history of "the artistic representation of gayness, homosociality, the rhetoric of friendship and polymorphous perversions as well as [to] the discourse surrounding this subject" ['(a könyv) részint a melegség, a homoszocialitás, a polimorf perverziók müvészi megjelenitéséről (szól), részint pedig arról a diskurzusról, mely ezt a témát övezte' (17)]. According to Csehy, this attention can pick up overt and covert gestures and manifestations of a highly plastic minority discourse, which, in turn, provokes or compels reaction. At the same time, this minority discourse significantly overlaps with as well as reinterprets and modifies the literary canons of its time (17).

The book's introduction, bearing the influence of Michel Foucault's discussions of sexuality, presents a brief survey of sexuality studies relying on a solid range of international and Hungarian scholarship. First there is a section on the distinction between essentialism and social constructivism, which is then followed by a short genealogy of the construction of the idea of "homosexual/ity" in the nineteenth century and its later developments in sexology, psychoanalysis, legal discourse, queer theory and social activism. After this genealogy, the book introduces Christopher Reed's framework for the analysis of the connection between art and

*e.timar@ceu.edu

$($ (c) $)$ EY

UILIS D-Sonte
New articles in this journal are licensed under a Creative Commons Attribution 4.0 International License.

This journal is published by the University Library System of the University of Pittsburgh as part of its D-Scribe Digital Publishing Program and is cosponsored by the University of Pittsburgh Press 
Timár, Eszter. "Csehy, Zoltán. 2014. Szodoma és környéke: Homoszocialitás, barátságretorika és queer irányulások a magyar költészetben ('Sodom and its Environs: Homosociality, Friendship Rhetoric and Queer Orientations in Hungarian Poetry'). Budapest: Kalligram.." Hungarian Cultural Studies. e-Journal of the American Hungarian Educators Association, Volume 10 (2017) DOI: 10.5195/ahea.2017.308

homosexuality as specifically applicable to the study of sexuality in Hungarian poetry. Csehy also implements a few more compatible approaches: a combination of Gregory Wood's work on the gay-male literary tradition and Jacob Stockinger's coinage of homotextuality, as well as Marita Keilson-Lauritz's work on homosexual constellations. All these scholars work with the understanding that what we nowadays see as homosexual identity is far from the diversity of olden-days legacies of same-sex friendship or bonding and their social policing.

While the logic of the largely historical-tropological organization is somewhat cryptic, the sections offer cogent examples of textual analysis, paying consistently close attention to textual nuance as well as outstanding assessments of the reception of primary texts in literary criticism. Indeed, it is impossible to list all of the noteworthy points of the volume. I would like to emphasize the scholarly brilliance of the numerous chapters on Hungarian poetry (and its relevant international contexts across the ages) predating the nineteenth-century emergence of a massive cultural anxiety about homosexuality as a riddle of nature, and suggest that in the light of queerness "old" Hungarian poetry is a vivid and complex textual corpus. In lieu of a comprehensive summary, let me say that I was often surprised by how engaged I became reading the initial sections; for instance I was amused by delving into Janus Pannonius's blue side or found it refreshing to read about the parallels between Virgil's and Zrinyi's treatments of fraternal virtue from another point of view than those with heteronormative bias.

As we move along history, the nineteenth century offers an impressive tableau of the great canonized poets. Let me, however, point out in more detail the excellent series of sections on Kálmán Thaly (1839-1909), a nationalist poet and historian of the second half of the nineteenth century. As Csehy illustrates closely, Thaly appears as somewhat of an anti-hero in Hungarian literary history: his poetic work focuses on the nationalist idealization of the poetry of the kuruc (anti-Habsburg rebels of the Rákóczi Uprising), and while he claimed to have collected and edited some of the kuruc poetry he published, after his death it was discovered that he had in fact penned those himself. This scandal marked him as a disingenuous poet and the cultural regime of the Communist era used this poetic masquerade as a justification for demonizing Thaly as they wanted to use kuruc poetry to celebrate the voice of the oppressed classes instead of promoting nationalism.

Csehy navigates the history of the literary criticism on Thaly's work in order to suggest that the idealization of homosocial male friendship, typical of Thaly's poetry, which is even more prevalent in his deployment of the motif of the kuruc outlaws' desperate loneliness and their resultant expressions of melodramatic, passionate love, combined with Thaly's penchant for selfconcealing masquerades (including his preference for prosopopeia in the form of passing his poetry as the folk tradition of a hundred years before his time), ascribes to his poetry a strong queer sensibility. This sensibility receives a theoretical shade when Csehy quotes Thaly the historian on the modern era, as "though more 'emancipated' [than older times], chasing its nasty pleasures with more zest in secrecy under the guise of innocence, [it] favors the demonstration of squeamishness" ['voltaképpen sokkal 'emancipáltabb' korunk, mely szép szín alatt titokban jobban üzi undokságait - külsöleg finnyáskodni szeret'] (311). Csehy’s reader may find a significant resonance between this remark and Foucault's thoughts on the emergence of modern biopolitics, but Csehy does not go so far as suggesting that Thaly is a queer hero, nor does he give the impression that he is the first one to take into account the homoerotic aspects of Thaly's 
Timár, Eszter. "Csehy, Zoltán. 2014. Szodoma és környéke: Homoszocialitás, barátságretorika és queer irányulások a magyar költészetben ('Sodom and its Environs: Homosociality, Friendship Rhetoric and Queer Orientations in

Hungarian Poetry'). Budapest: Kalligram.." Hungarian Cultural Studies. e-Journal of the American Hungarian Educators Association, Volume 10 (2017) DOI: 10.5195/ahea.2017.308

works. Instead, by synthesizing the existing scholarship on Thaly and offering his own analyses, Csehy shows that a textual corpus is open to radical reinterpretation. Perhaps even more importantly, this case of literary history repeatedly deciding to exclude a specific corpus from its canon highlights very clearly the political nature of the ways in which canonizing intentions rely on a tacit heteronormative bias.

The twentieth century brings a fantastically rich repertoire of queerly gendered attraction (e.g. in the unapologetic works of József Berda or György Faludi, or in the rhetoric of clandestine perversions in of Minka Czóbel's works) which later, reaching into the early decades of the twenty-first century, develops a diverse poetic language of openly thematized gay experience (e.g. in the works of Ádám Nádasdy, András Gerevich, and Kinga Fabó). I should also note that Csehy pays very close attention to women authors (cis and non-cis women alike) as well as to literary criticism informed by gender studies, which is an important part of the book's discussions.

In the conclusion Csehy suggests that the historical corpus he surveyed throughout his book features the literary legacies of sodomy, the rhetoric of friendship, homosexuality, and queerness in four paradoxical constellations of making meaning. These include an Arcadian imagery idealizing friendly bonds of a golden past, the resistance of conventional gendered norms by circumventing or exaggerating them, affirmation of these norms via language ploys, and finally, the development of an autonomous poetic language voicing an alternative culture. The resulting density of poetry, textual analysis, and theory makes this work invite future research on several intriguing questions. For example, if the distinction between friendly and romantic love seemed consolidated in the nineteenth century, in part by medical and legal reification of homosexuality as a social threat (765), then why should we still hold on to this distinction when we read texts prior to this reification?

The power to compel important questions that are not at all limited to the domain of poetry, Hungarian or other, is one of the many contributions for which Csehy's work is so valuable. But the main merit of this study is that from now on we have an exhaustively documented diverse resource to rely on when studying the myriad and intricate relations between gender and literature in Hungarian culture and elsewhere. This means that this book is useful for all audiences: its encyclopedic nature ensures that poetry lovers will value its solid overview of Hungarian poetry, and that students will find relevant scholarship on the era or poet they are working on as well as great examples of excellent literary analysis. At the same time, scholars specializing in queer literary analysis will delight in the cogent and vivid theoretical insights peppering the course of the text. All these make Zoltán Csehy's Szodoma és környéke a scholarly milestone and an intriguing read that is worthy of translation to other languages. 